\title{
Conservation status of shark fish in the Aceh province coastal area
}

\author{
Hazia Awanis ${ }^{1}$, Ismul Huda ${ }^{1 *}$ and Muhammad A. Sarong ${ }^{1}$ \\ ${ }^{1}$ Biology Education Department, Universitas Syiah Kuala, Aceh, Indonesia
}

\begin{abstract}
Shark fishing activities in Aceh Province take place in the Straits of Malacca and the Indian Ocean. Knowledge and understanding of fisher in the coastal areas of Aceh Province regarding shark protection and conservation regulations are still very limited so that the exploitation of sharks has increased. Observations were made in five coastal areas of Aceh Province. The sample in this study is the shark fish fished of fishermen. This study aims to determine the percentage of conservation status based on IUCN and CITES of sharks fish fished by the fishermen in the coastal region of Aceh Province. Data was collected in April-May 2019 using the survey method. Descriptive analysis results showbased on IUCN one species (10\%) in the least concern category (LC), five species $(50 \%)$ in the category of near threatened (NT), two species $(20 \%)$ in the vulnerable category (VU), one species (10\%) in the endangered category (EN), while one species (10\%) in the critically endangered category (CR) and based on CITES two species (20\%) in category nonendangered species, but if the trade continues without regulations, with extinction, it will be threatened (the Appendix II CITES). From these results, it can be concluded that the sharks caught in the coastal area of Aceh Province as a whole are in the IUCN red list category.
\end{abstract}

Keywords: sharks, conservation, coastal, Aceh.

\section{Introduction}

Indonesian waters are the largest shark producing country [1]. Based on studies there have been recorded 114 species of sharks found in Indonesian waters [2] and potentially to be utilized [3]. Understanding and knowledge of fishermen about shark conservation is very necessary so that fishermen know the type of shark that is protected and know the rules related to shark fishing activities [4]. Shark exploitation in Indonesia is carried out in the region's nursery ground and feeding ground. Lampulo Ocean Fishery Port is one of the ports that land sharks. 747 sharks caught by fishermen identified in Lampulo PPS were classified into 16 families, 20 genera and 32 species [5]. If the arrest continues, the balance of the marine ecosystem will be disrupted and the top predators experiencing extinction [6]. There are five shark species included in Appendix II, four species of which are found in Indonesia, 3 species of hammerhead shark (Sphyrna lewini, Sphyrna zygaena, Sphyrna mokarran) and cowboy shark (Carcharhinus longimanus) [7] Shark fishing activities take place in the Malacca Strait and Indian Ocean waters. Knowledge and understanding of fishermen in coastal areas of Aceh Province regarding the conservation and regulation of shark protection is still very limited so that the exploitation of sharks hasincreased. The purpose of this study is to determine conservation status based on the International Union for Conservation of Nature's (IUCN) and the Convention on International Trade in Endangered Species of Wild Fauna and Flora (CITES) in the coastal region of Aceh Province.

\section{Materials and Methods}

This research was conducted in April-May 2019. Observations were carried out in the coastal area of Aceh Province, the coastal area was divided into 5 regions (Figure 1). Each region is represented by one district that has a Fish Auction Site. Determination based on the presence or absence of shark fishing activities.

\subsection{Data collection}

Data collection using survey methods. The survey was conducted using an observation sheet, an observation sheet to record sharks caught by fishermen in the coastal areas of Aceh Province [5]. Data collection is conducted from April to May 2019.

\footnotetext{
*Corresponding author: ismulhuda@unsyiah.ac.id
} 


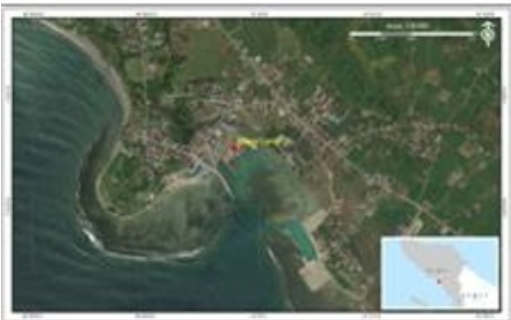

(a)

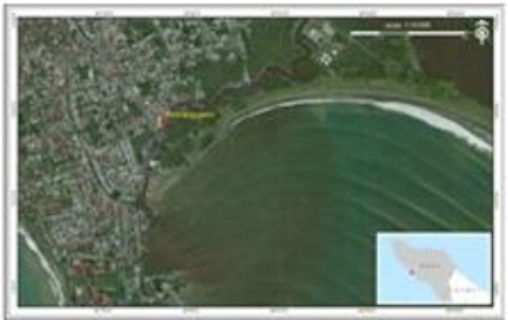

(b)

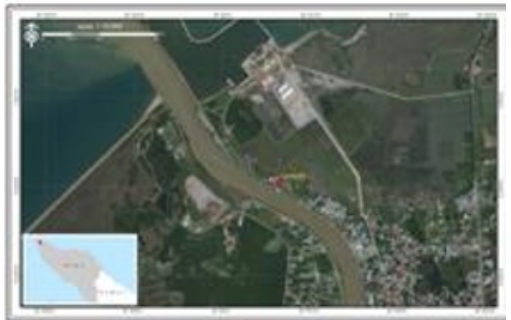

(c)
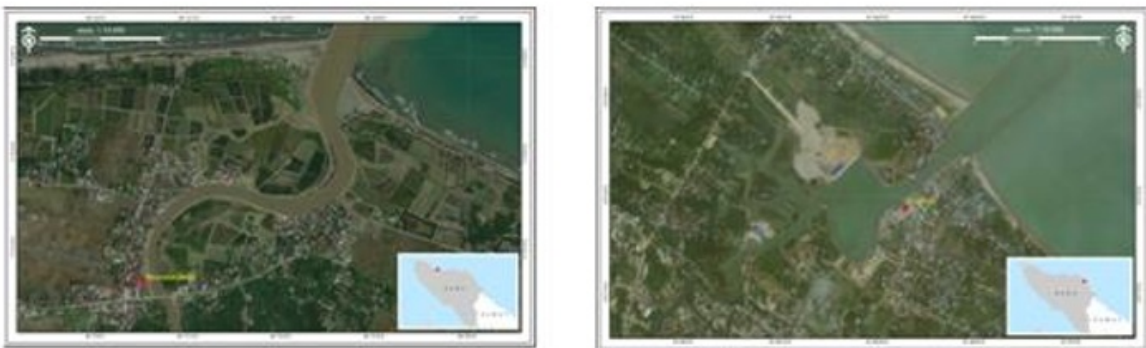

Figure 1. Observation Location Map

Note: (a) South Aceh Province in Labuhan Haji subdistrict Pasar Lama village (b) West Aceh Province in Johan Pahlawan sub-district Padang Seurahet village (c) Banda Aceh City Region in the sub-district Lampulo village lampulo (d) North Aceh Province in Meuredu subdistrict Meunasah Balek village (e) East Region

\subsection{Data Analysis}

Analysis of the data used is descriptive analysis. Descriptive analysis aims to provide an over view of the results of the study, the instrument to determine the conservation status used is the IUCN Red List, analyzed using the IUCN redlist web[8] and CITES was analyzed using the CITES check list [9]. Shark identification uses the Economically important sharks and rays of Indonesia[10].

\section{Results and Discussion}

Based on the results of research on the conservation status of sharks caught by fishermen in the coastal areas of Aceh Province based on IUCN found in the least concern, near threatened, vulnerable, threatened and critical categories while based on CITES in the CITES Appendix II category.

Table 1. Conservation Status of Sharks Captured by Fishermen in Coastal Areas of Aceh Province

\begin{tabular}{|c|c|c|c|c|c|c|c|}
\hline \multirow[t]{2}{*}{ No } & \multirow[t]{2}{*}{ Area Name } & \multirow{2}{*}{$\begin{array}{l}\text { Intemasional } \\
\text { Name }\end{array}$} & \multirow[t]{2}{*}{ Family } & \multirow[t]{2}{*}{ Genus } & \multirow[t]{2}{*}{ Spesies } & \multicolumn{2}{|c|}{ Conservation Status } \\
\hline & & & & & & $\begin{array}{l}\text { IUCN red } \\
\text { List }\end{array}$ & CITES \\
\hline 1 & $\begin{array}{l}\text { Hiumada/Yee } \\
\text { beuton }\end{array}$ & Bull shark & Carcharhinidae & Carcharhinus & Carcharhinus leucas & NT & \\
\hline 2 & $\begin{array}{l}\text { Hiubuas/Yee } \\
\text { Gapeuh }\end{array}$ & $\begin{array}{l}\text { Blactip Reef } \\
\text { Shark }\end{array}$ & Carcharhinidae & Carcharhinus & $\begin{array}{l}\text { Carcharhinus } \\
\text { melanopterus }\end{array}$ & NT & \\
\hline 3 & $\begin{array}{l}\text { Hiu buas/yee } \\
\text { bulok }\end{array}$ & $\begin{array}{l}\text { Spot-tail } \\
\text { Shark }\end{array}$ & Carcharhinidae & Carcharhinus & Carcharhinus sorrah & NT & \\
\hline 4 & $\begin{array}{l}\text { Hiukarang/Yee } \\
\text { kareung }\end{array}$ & $\begin{array}{l}\text { Whitetip Reef } \\
\text { Shark }\end{array}$ & Carcharhinidae & Triaenodon & Triaenodonobesus & NT & \\
\hline 5 & $\begin{array}{l}\text { Hiumartil/Yee } \\
\text { nimba }\end{array}$ & $\begin{array}{l}\text { Scalloped } \\
\text { hammerhead }\end{array}$ & Sphymidae & Sphyrna & Sphyrna lewini & EN & Appendik II \\
\hline 6 & $\begin{array}{l}\text { Hiu tikus/Yee } \\
\text { tikoh }\end{array}$ & $\begin{array}{l}\text { Thresher } \\
\text { Shark }\end{array}$ & Alopïdae & Alopias & Alopias pelagicus & VU & Appendik II \\
\hline 7 & $\begin{array}{l}\text { Hiupasir/Yee } \\
\text { anoe }\end{array}$ & $\begin{array}{l}\text { White spotted } \\
\text { guitarfish }\end{array}$ & Rhychobatidae & Rhychobatus & $\begin{array}{l}\text { Rhynchobatus } \\
\text { australiae }\end{array}$ & $\mathrm{CR}$ & \\
\hline 8 & $\begin{array}{l}\text { Hiupasir/Yee } \\
\text { Anoe }\end{array}$ & $\begin{array}{l}\text { Indo } \\
\text { Wobbegong }\end{array}$ & Orectolobidae & Orectolobus & Orectolobus ornatus & LC & \\
\hline 9 & $\begin{array}{l}\text { Hiuminyak/Yee } \\
\text { Minyeuk }\end{array}$ & $\begin{array}{l}\text { Indonesia } \\
\text { Highfin } \\
\text { Spurdog }\end{array}$ & Squalidae & Squalus & Squalus hemipinnis & NT & \\
\hline 10 & $\begin{array}{l}\text { Hiukacang/Yee } \\
\text { urot }\end{array}$ & $\begin{array}{l}\text { Sicklefin } \\
\text { Weasel Shark }\end{array}$ & Hemigaleidae & Hemigaleus & $\begin{array}{l}\text { Hemigaleus } \\
\text { microstoma }\end{array}$ & VU & \\
\hline
\end{tabular}

Table 1 shows the conservation status of sharks caught by fishermen in the coastal areas of Aceh Province as awhole included in the IUCN Red List. Of the nine IUCN Red List categories, one species category critically endangered (CR) Rhynchobatus australiae and one species category last concert (LC) Orectolobus ornatus. Two species are listed in Appendix II CITES, Sphyrna lewini and Alopias pelagicus. The following is a 
percentage of the conservation status of sharks caught by fishermen in the coastal areas of Aceh Province, This

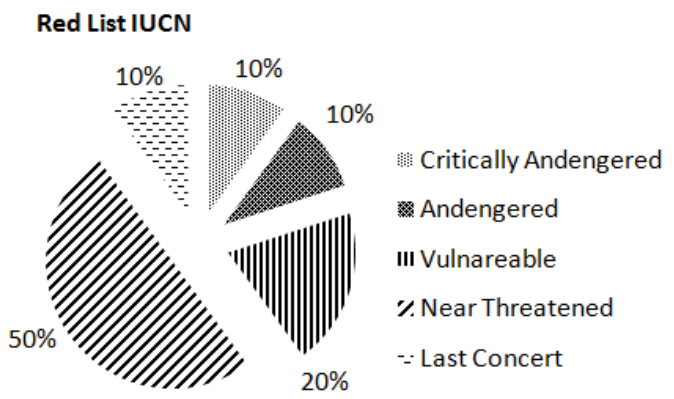

Figure 2. Conservation Status Based on IUCN and CITES.

\subsection{Conservation Status Based on IUCN}

Category last concert (LC) is a shark that has been evaluated but does not fall into any category, one species $(10 \%)$ was found in this category that is Orectolobus ornatus. Sharks in the category of near threatened are sharks whose existence is approaching endangered, if there is no management effort, it is believed that the species will be threatened in the future [11]. Five species $(50 \%)$ were found in this category that is Carcharhinus leucas, Carcharhinus melanopterus, Carcharhinus sorrah, Triaenodon obesus, and Squalus hemipinnis.

Vulnerable categories are sharks that are feared to have a high risk of extinction in nature, found two species (20\%) in this category Alopias pelagicus and Hemigaleus microstoma. The critically endangered categoryis a type of shark that has a very high risk of experiencing extinction in nature and in fear of going extinct shortly, found one species (10\%) in this category that is Rhynchobatus australiae [11]. Shark species that are included in the endangered category are shark species that have a high risk of extinction in the wild due to the large catches of this species population, one species (10\%) found in this category was Sphyrna lewini.

\subsection{Conservation Status Based on CITES}

Based on the results of the research found two species included in Appendix II of CITES are A.pelagicus and S.lewini. Regulations regarding the location of hammerhead shark fishing in Indonesia need to be carried out because $S$. lewini has been declared endangered. $S$. lewini is a species whose trade can only be done in Indonesian territory, this matter is written in PERMEN KP No. 59 of 2014 and also in PERMEN KP No. 48 of 2016 [12]. Indonesia has regulations on shark protection, found 8 species of 117 species of sharks in Indonesia which are protected or circulated at international conventions, the shark species Rhincodon typus, S. lewini, S. mokarran, S. zygaena, C. longimanus, C. falciformis, A. pelagicus, A. superciliosus.

The status of shark conservation is regulated based on the IUCN red list and protection is based on the PERMEN KP while the global agreement governing the international trade in threatened species of plants and animals is CITES. CITES makes three appendices the percentage can beseen in Figure 2 as follows

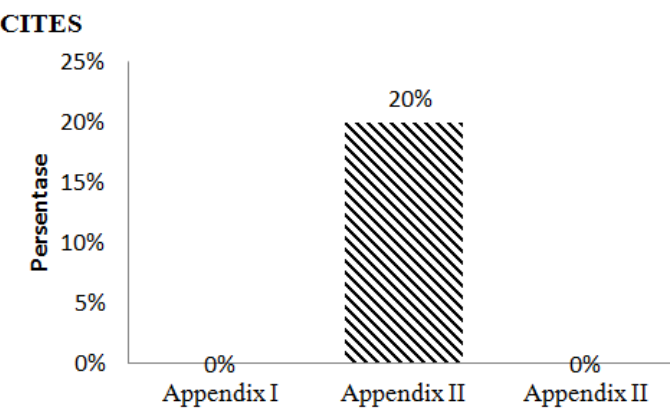

(Appendix) consisting of Appendix I, Appendix II and Appendix III. The shark species included in Appendix II CITES list are $A$. pelagicus, $A$. superciliosus, $C$. falciformis, and S. lewini [13]. Two species were included in the Appendix II CITES list, namely A. pelagicus and $S$. Lewini.

The development of shark trade that continues to increase and the increasingly intensive fishing of sharks have made several species vulnerable to population decline in Indonesian waters. Catching sharks is influenced by several factors, one of which is people's consuming behavior towards sharks.

Sharks consumers have an important role in conservation [14]. Many actions can betaken to reduce over-exploitation, one of them can beseen from the behavior of fishermen who have been given guidance on conservation. Such directives will affect whether or not conservation measures are successful[15].

\section{Conclusion}

Conservation status of shark fish in the Aceh province coastal area namely one species $(10 \%)$ in the least concern category (LC), five species $(50 \%)$ in the category of near threatened (NT), two species $(20 \%)$ in the vulnerable category (VU), one species $(10 \%)$ in the endangered category $(\mathrm{EN})$, while one species $(10 \%)$ in the critically endangered category (CR) and two species (20\%) in Appendix II category (non-endangered species, but will be endangered if trade continues in the absence regulations) CITES.

\section{Acknowledgments}

Thank you to the Aceh Province Maritime and Fisheries Office.

\section{References}

1. Sembiring A, Pertiwi NPD, Mahardini A, et al. : DNA barcoding reveals targeted fisheries for endangered sharks in Indonesia. Fisheries Research. 2015; 164:130 134.

2. Fahmi, Dharmadi : Tinjauan Status Perikanan Hiu dan Upaya Konservasinya di Indonesia. Jakarta: Direktorat Konservasi Kawasan dan Jenis Ikan. 
http://lipi.go.id/publikasi/tinjauan-status-perikanan-hiudan-upaya-konservasinya-di-indonesia/1541; 2013.

3. Wibowo S, Susanto H : Sumber daya dan Pemanfaatan Hiu. Jakarta: Penebar Swadaya. 2005.

4. Imanuel E, Hendrawan IG, Puspitha NLPR : Persepsi Nelayan Terhadap Status Konservasi Hiu dan Pengaruhnya Terhadap Penangkapan Hiu: Studi Kasus di Kabupaten Badung, Provinsi Bali. Journal of Marine and Aquatic Sciences. 2018;4(2): 244.

5. Lesmana F, Ulfah M: Identifikasi Spesies Hiu yang Tertangkap di Perairan Utara Aceh. Jim.Unsyiah.Ac.Id. 2018; 3:39-45.

6. Hardiningsih W, Purwadi H, Latifah E: Dampak Ketiadaan Pengaturan Kuota Ekspor Hiu Tikus. Jurnal PJIH. 2017; 4 (3):588.

7. Convention on the International Trade in Endangered Species of Wild Flora and Fauna Appendise I, II, and III. Geneva. https://www.cites.org/eng/disc/text.php. 2019.

8. IUCN Red List of Threatened Species. Version 2019. https://www.iucnredlist.org/2019.

9. Cheklist of CITES Species. http://checklist.cites.org/\#/en. 2019.

10. White WT, Last PR, Stevens JD, et al.: Economically important sharks and rays of Indonesia. The British Journal of Psychiatry. 2006; 112(483): 211-212.
11. Fahmi, Dharmadi : Status perikanan hiu dan aspek pengelolaannya. $2005 ; 30(1)$ : $1-8$.

12. Peraturan Menteri Kelautan dan Perikanan Republik Indonesia No 48 Tahun 2016 Tentang Perubahan Kedua Atas Peraturan Menteri Kelautan dan Perikanan No 59 PERMEN KP 2014 Tentang Larangan Pengeluaran Ikan Hiu Koboi (Carcharhinus longimanus) dan Hiu Martil Dari Wilayah Negara Republik Indonesia Keluar Negara Republik Indonesia (Jakarta: KKP).

13. Suyastri, C: Politik Lingkungan: Penanganan Perdagangan Satwa dengan Identifikasi Pasal-pasal Perundangan CITES Political Environment : Wildlife Trade Management by CITES Articles Identification. Jurnal Kajian Politik dan Masalah Pembangunan. 2015; 11(01): 1613-1622.

14. Giglio VJ, Ternes MLF, Luiz OJ, et al. : Human consumption and popular knowledge on the conservation status of groupers and sharks caught by small-scale fisheries on Abrolhos Bank, SW Atlantic. Marine Policy. 2018; 89:142-146.

15. O'Bryhim JR, Parsons ECM, Gilmore M, et al. : Evaluating support for shark conservation among artisanal fishing communities in Costa Rica. Marine Policy. 2016;71: 1-9. 